\title{
ПОСТПЕДАГОГИЈА: РАЗВОЈ КОНЦЕПТА И НАЈЗНАЧАЈНИЈЕ ПОСТАВКЕ ${ }^{12}$
}

\author{
Јелена Петровић ${ }^{3}$, Марија Ђорђевић \\ Универзитет у Нишу, Филозофски факултет, Департман за педагогију
}

\begin{abstract}
Ancmpaкm: Намера овог рада била је да се изврши теоријска анализа концепције постпедагогије, теоријских и практичних схватања представника постпедагогије, са акцентом на однос одраслих и деце. Такође, у анализи смо настојали да утврдимо постпедагошки став према традиционалном схватању појма „васпитање“, као и да се дотакнемо актуелности ове концепције. Слобода и одговорност детета, поштовање детета и његова субјекатска позиција, али и љубав према себи и аутентичност - кључни су циљеви и основа постпедагошке концепције. Постпедагошко мишљење подразумева радикалан раскид са традиционалном педагогијом. Равноправни односи успоставиће се, сматрају постпедагози, тек када се одрасли одрекну васпитања и убеђења да је човек, дете - homo educandus, биће којем је васпитање потреба и где разум има водећу функцију. Постпедагошко схватање односа према детету није пука могућност о којој се случајно говори: оно је обележје времена у којем живимо и у којем ће наша деца тек живети. Постпедагози позивају савремено друштво да преиспита своје педагошке вредности на којима се заснива однос одраслих и деце.
\end{abstract}

Кључне речи: амикација, антипедагогија, васпитање, однос одраслих и децее, постмодерна, постпедагогија.

\section{Увод и приступ проблему}

У новије време сматра се да су односи које дете успоставља са особама из своје околине основа за дететов развој и учење. Међутим, није увек било тако. У највећем делу досадашње историје дете и детињство били су у сенци родитеља и родитељства. Деца су била у инфериорном, потчињеном положају у односу на одраслог. Доминација одраслог сматрана је очигледном и по себи

\footnotetext{
${ }^{1}$ Рад је настао као резултат рада на пројекту број 183/1-16-8-01, под називом Унапређивағе $и$ осавремеъавање основних академских студија педагогије, финансираном од стране Филозофског факултета у Нишу.

${ }^{2}$ Ово истраживање финансијски је подржало Министарство просвете, науке и технолошког развоја Републике Србије.

${ }^{3}$ jelena.petrovic@filfak.ni.ac.rs
} 
разумљивом чињеницом. Говорећи о односу одраслог и детета, говорило се о улози одраслог, о њиховом понашању и пракси родитељства, док би детету био посвећен тек по неки део, као мање битном фактору тог односа.

Демократизација односа између људи у новијој историји најпре западног друштва увела је нове стандарде у опхођењу са децом. Дете се све више доводи у положај равноправности са одраслима. Дефинишу се принципи проглашења и заштите његових права, чији је законски облик прописан Конвенцијом УН о правима детета из 1989. године. Двадесети век проглашен је веком детета (Key, 2000; Potkonjak, 2003).

Родитељи и учитељи савременог доба у свом односу са децом требало би да се ослањају на вишевековна педагошка достигнућа у теорији и пракси. Међутим, упоредо са тиме, треба узети у обзир историјски тренутак у којем се пружа могућност, а захтева и одговорност, за нов приступ детету. Ми овде користимо појам постпедагошки, који логички и садржајно стоји у вези са општеприхваћеним појмом постмодерна чија је употреба распрострањена у савременом мишљењу (Gudjons, 2002; Kraljačić, 2016). Нови токови педагошког мишљења у свету захтевају и нов начин формулисања проблема и хипотеза у педагошком истраживању.

Предмет овог истраживања је однос постпедагогије према традиционално схваћном појму васпитања. Циљ истраживања је да се изврши теоријска анализа концепције постпедагогије, теоријских и практичних схватања представника постпедагогије, пре свега у контексту односа одраслих према деци, као и да утврдимо постпедагошки став према васпитању као системском и планском утицају на целокупни развој детета. Покушаћемо да одговоримо на питања: Које су основне поставке концепције постпедагогије? Како је настала ова концепција? Како се ова концепција данас уклапа у основе постмодерне? Како се у постпедагогији гледа на дете? Како постпедагошка концепција данас гледа на васпитање у традиционалном смислу?

\section{Дефинисање основних појмова}

На почетку проучавања, најпре би требало одредити основне појмове и њихово значење, како би се проучавање овог сегмента педагошке стварности учинило јасним и доступним читаоцима.

Појам дете посматраћемо као конструкцију одраслих насталу у професионалним или свакодневним дискурсима (Kehily, 2009). Начин на који одрасли схватају природу детета повезан је са тиме како одрасли дефинишу методе опхођења према деци, права детета, положај детета у друштву, као и квалитет односа који одрасли граде са децом (Jul, 2018). Међутим, треба указати и на чињеницу вишедимензионалности савременог света у ком живимо, у коме су се међуљудски односи променили, а са њима и симболичко изражавање детињства у правцу сложенијег диференцирања културолошког идентитета појединца (Jul, 2017). Овај развој је на много начина повезан и са променама међу 
генерацијама, развојем науке, технике и технологије. Корените промене доводе и до вредносне промене у промишљању детета, васпитања и педагошких циљева, па се, уместо да се „делује уместо и у име” детета, настоји да се дете постави као субјекат властитог чињења, о чему нарочито говоре постпедагози.

У другој половини XX века појавиле су се бројне критике на рачун васпитања, школе и педагогије. Те критике исказане су у називима као што су: антиауторитарно васпитање, алтернативна школа, нови односи са децом или односи без васпитања, а схватања која су исказана у свима њима названа су антипедагогија или постпедагогија.

Синтагма алтернативне школе односи се на школе које представљају алтернативу традиционалној школи, настале шездестих и седамдесетих година XX века. Оне се развијају захваљујући обновљеном интересовању за педагошке приступе разичите од традиционалних и захваљујући потреби да се школа реформише и учини отворенијом за дете и средину у којој постоји. Подстицај су добиле и из хуманистичке психологије (Milutinović, 2011), али се ипак сматрају наслединицима прогресивистичког наслеђа. Међу алтернативне школе данас убрајају се и оне које су настале у оквиру реформне педагогије, али су успеле да одрже континуитет рада и постојања до данашњих дана (Петровић, 2015). Неке од најпознатијих алтернативних школа и данас су Монтесори, Валдорф и Далтон школе, којима је заједничко: слобода у васпитању, ослобађање детета од стега крутих система школе и наставе, и пружање простора за развој његових потенцијала и унутрашњих снага, поштовање индивидуалности и самосталности детета.

Са појмом постмодерна, што је, према Гудјонсу (Guljons, 2002: 17), ,jедна сасвим дифузна помодна реч“, повезује се далекосежни процес промена и критика „модерне“. Појмом „модерна“ означава се епоха од просветитељства до садашњости. Стање духа модерне означавала је идеја о просвећеном поретку у свету који напредује захваљујући разуму, где човек, употребом свог разума, спојено са моралношћу, може да од себе ствара субјект и да се као такав развија. Префикс „пост“ у појму „постмодерна“ сигнализира „крај“ ове епохе и тог начина размишљања, и тиме циља на драматичну промену најближе садашњости на пољу уметности, књижевности, филозофије, друштвене свакодневице, васпитања. Провокација постмодерне не лежи само у њеној критичкој анализи културе модерне која постаје самодеструктивна (Guljons, 2002), која нема наде након Аушвица, како сматра француски филозоф и социолог постмедирнизма - Лиотар (Lyotard, према: Kraljačić, 2016), него и у последицама којима се надамо, а које би настале услед губитка вере у легитимитет и оствареност подухвата модерне (више не постоји јединство које даје смисао, не постоји разлог који даје сигурност...). Према Гудјонсу је онда постмодернистичко размишљање - прихватање плуралности животних стилова, спремност да се у једној особи реализују различити идентитети, толеранција према индивидуалности других. Постмодерна је у педагогији доживљена као угрожавање властитих теоријских поставки. Такође је за педагогију значила крај просветитељства, одрицање од трагања за истином, плуралност уместо обавезности, нову непрегледност (Gojkov, 2006). 
За појам антипедагогија у релевантној педагошкој литератури не постоји јединствено одређење. Под појмом антипедагогија подразумева се „назив за доста разнородна схватања настала у последњим деценијама двадесетог века којима је, ипак, заједнички став да није потребна педагогија као јединствена и целовита теорија (концепција, наука) о васпитању; такав став резултат је како оправдане критике постојеће педагогије и њених слабости (нпр. претеране идеологизације, запостављања индивидуалитета детета, прецењивања школског образовања и васпитања и сл.), тако и нихилистичког и критизерског става према педагогији као таквој” (Педагошки лексикон, 1996: 27). Антипедагогија представља и алтернативни покрет за нови стил живота у коме васпитање замењују нови односи, пријатељство са децом како се назива и регистровано удружење које је основао Хубертус фон Шонебек (Hubertus von Schönebeck), педагог, психолог, терапеут, најпознатији гласноговорник анти/постпедагогије. Шонебек пише да је антипедагогија била 1975. године најпре књига Екехарда фон Браунмила (Braunmühl), једна идеја, „,апстрактно сазнање које је пријало“, али „антипедагогија је више од просвећивања, од исказа о неком предмету. Оно што је Браунмил у својој књизи ухватио оштрином свог интелекта био је само дашак револуције срца, који на крају доба патријархата обилази свет и најављује ново доба“" (Šonebek, 2002: 99-100).

Постпедагогија као покрет јавља се 1978. године, оснивањем удружења Пријатељство са децзом са седиштем у Минстеру. Ово удружење је члан Немачке добротворне заједнице, где се окупљају покрети који доприносе општем друштвеном добру. Њихов рад се састоји од многоструких послова у јавности како би концепт Пријатељство са децуом / Подстицање уместо васпитања постао познат ван и унутар земље (штампање литературе, организовање семинара, курсева).

\section{1. Друштвени и теоријски контекст настанка постпедагошке мисли}

Развој друштва у XIX веку обележен је напретком у наукама, применом многобројних научних открића и сазнања, увећавањем и афирмацијом индустријског и финансијског капитала, а настајале су и различитости као последице деловања природних чинилаца, као и развојних потенцијала људи и друштва тог времена. Европа се у том периоду издваја од осталих делова света по најефикаснијим саобраћајницама, достигнућима индустријске производње, по уређености и функцији држава. Европу такође у том периоду налазимо као континент са најбројнијим универзитетима и школама, најмасовнијим институцијама образовања и са великим средиштима модерних центара културе и уметности (Петровић, 2015). С друге стране, индустријска револуција у другој половини XIX века тражила је велики број физичких радника, израбљиваних по фабрикама, међу њима и велики број деце. На дете се гледало као на одраслог човека у малом. Затим у свету настаје дестабилизација монархија, поли- 
тичког поретка уопште, чиме се узрокује неизбежност Првог светског рата. Поремећени односи у политичком контексту изазивали су кризне ситуације које су утицале и на положај образовања (Maras et. al, 2018), па и васпитања.

У таквом турбулентном политичко-економском окружењу настају различити друштвени покрети, као што су покрети за људска права, права радника, права жена и остали. Увиђа се потреба другачијег васпитања и образовања, те брига о деци. Следи настанак реформске (,нове“) педагогије. Пред сам почетак XX века, шведска ауторка Елен Кеј објавила је књигу Век детета (Key, 2000), делимично утемељену на сазнањима тада младе науке - развојне психологије (која је указала на постојање специфичних фаза дечјег развоја). Верујући да почиње доба које ће више поштовати и разумети дете, књигом је најавила бројне промене које су (само формално) стварно обистињене декларацијом и конвенцијом о правима детета пред сам крај XX века. Хуманистички и педагошки погледи Елене Кеј ипак се нису остварили (Михајловић, 2013). Желела је да нови, XX век буде век детета, да се у васпитању поштује његова личност. Припадала је покрету слободног васпитања. Полазећи од идеја Русоа, Песталоција и других њима сличних педагога, Кеј је заговарала педоцентрични приступ васпитању и образовању детета. Њен педоцентризам је због неразумевања посебности дечјег развоја често био критикован, јер је био другачији од ондашњег устаљеног погледа на дете као „човека у малом“, генерално „злочестог“ детета којег треба „дисциплиновати“. Тиме је реафирмисала Русоове и Песталоцијеве идеје о човеку који је по нарави добар, и да су цивилизацијски утицаји одговорни и криви за васпитање.

Шездесетих и седамдесетих година XX века, долази до развоја хуманистичке психологије, чији су најпознатији представници Абрахам Маслов (Abraham Maslow) и Карл Роџерс (Carl Rogers). Хуманисти наглашавају важност суштинских људских проблема као што су аутентичност, вредности, имагинација, идентитет. На темељима хуманистичке психологије, развијала се и постпедагогија. Хубертус фон Шонебек, немачки педагог, творац филозофије „амикације“, усавршавао је код Роџерса психодинамику групе и хуманистичку психологију, говорећи о настанку антипедагогије као правца, Карла Роџерса, хуманистичког психолога, ставља на прво место међу оне који су припремили пут антипедагогији: наука (К. Роџерс, Ф. Лебоаје), покрет за дечја права (Р. Фарсон, Џ. Холт, Е. фон Браунмил) и социјална антропологија (Боас, М. Мид, Б. Рут).

Сам Роџерс је о новим односима писао следеће: „Кроз своје односе са другим људима схватио сам да, гледано на дуже стазе, ништа нећу постићи ако се понашам као да сам нешто што нисам... Кад сам оно што јесам, и односи у које ступам постају прави... Но можда је још значајнија чињеница да се ови људи мењају захваљујући томе што их разумем... Стигао сам до кључног сазнања које је за мене било изузетно значајно:... Чињеница да себи могу да допустим да разумем другу особу има за мене огромну вредност..." (Rodžers, 1985: 21-23). Хуманистичке вредности оваплоћене у Роџерсовој психологији данас су саставни део стремљења у многим друштвеним наукама. Карл Роџерс 
није само припремио пут анти/постпедагогији, његова схватања и терапеутска искуства прихваћена су данас и од многих педагога, психолога и терапеута.

\section{2. Однос одраслих и деце у постпедагошкој концепцији}

Дефинишући антипедагогију као „ново осећање живота и нови сензибилитет, посебно у равноправним односима са децом“, Граорац (2015) истиче односе одраслих и деце у први план постпедагогије. Равноправне односе Шонебек најчешће назива: нови односи без васпитања, партнерски, амикативни, ређе демократски.

Постпедагози истичу субјекатску позицију детета, притом гледајући на децу као на стварне људе који стоје иза сваког васпитања, а које желе да упознају на егзистенцијалном нивоу: „Ко сам ја? Ко си ти?“ Из ове основе креће се новим путем до детета који није зацртан са педагошке тачке гледишта, већ нескривен и радикално искрен: од себе до субјективног идентитета сваке младе особе. Ова позиција, која је основана у постмодернизму, заснива се на егзистенцијалној једнакости људи и њиховог знања и на тај начин напушта педагогију и васпитање вођено методама и техникама, стратегијама и дидактиком, тренингом личности и комуникације, припремама и надзором, одређивањем циљева, мотивисањем, евалуацијама, анализама (Schoenebeck).

Шонебек равноправним односима деце и одраслих жели да обезбеди оптималне услове за развој личности и укине васпитање. Залажући се за отворено васпитање, Александра Марјановић критички посматра „педагогизацију детињства“ као друштвено-историјску појаву чије превазилажење постаје могуће успостављањем равноправних односа и заједничким живљењем деце и одраслих. Ова ауторка у равноправним односима види прави и једини пут да се прихвате потребе и особености детињства, и оне аутентично култивишу, а да се деца као група на аутентичан начин интегришу у друштвену заједницу (Граорац, 2015).

Самоодговорност и субјективност значе независан и суверен унутрашњи свет за сваку поједину особу. „Унутрашњи светови“ постоје свуда као универзални принцип унутрашње структуре: у атомима, камењу, биљкама, животињама, људима. Постоји темељно поштовање унутрашњег човековог света, у унутрашњи свет се никада не меша у смислу да тамо мора бити нешто што друга особа тамо не жели (Schoenebeck). Сличан приступ налазимо и код Марије Монтесори. Она инсистира на томе да док је „физичком ембрију потребна заштита мајчиног тела, духовном ембрију је потребна таква околина која га прихвата и у којој он осећа да га разумеју, дакле, околина која му пружа топлину, бригу, разумевање за његове проблеме, одобрава његове поступке и пружа му љубав“" (Минић, 2013, 150). Према постпедагозима, дете најбоље зна шта је за њега добро, што даље отвара питање самосталности и индивидуалне одговорности детета.

Ако је дете субјект у односу са одраслим, онда то захтева и одређену самосталност, али та самосталност захтева и одређену одговорност за сопствене по- 
ступке. Шонебек као основе пријатељског начина живота наводи следеће одреднице: љубав према себи, пуна вредност (сви су од почетка пуноправне особе), лична одговорност, суверенитет, еквиваленција (ништа и нико не стоји изнад или испод другог), субјективност (објективне истине одвојене од људи не постоје), беспрекорност (нико не може да погреши стварно - јер изнад појединца не постоји објективна мера), социјалност, поштовање унутрашњег света, асертивност у спољашњем свету, емпатија и слобода образовања (Schoenebeck).

Нема никога ко се данас неће позивати на љубав према деци. Међутим, стваран позитиван утицај на дете показују они који сами имају аутентичан став према животу и реалан однос према себи. Ако погледамо око себе, схватићемо да позитиван утисак на своје дете данас оставља онај ко је достигао стандарде савременог одрживог развоја и индивидуације, ко је изградио темељне врлине постмодерне етике индивидуалне одговорности, које данас називамо различитим именима: асертивност, присуство, конгруенција, емпатичност, ведрина и радост духа, прихватање ближњег.

Шонебек као главну одредницу амикације наводи концепт који је развио: љубав према себи. Шонебек је показао да је то обележје оних људи који су способни да успоставе пријатељство са децом. Заправо, он је чврсто уверен да се љубав према деци заиста може развити само ако себи допустимо да волимо себе такве какве јесмо. У овом контексту, Живковић (2010) тврди да постпедагошка љубав према себи данас представља бољи и сигурнији пут ка детету од образовања детета и педагошке љубави према детету.

У вези са овим принципом амикативног схватања, поставља се питање да ли ово није себично и недруштвено. Амикативна концепција на ово питање одговара: људи су друштвена бића од рођења. Самоодговорност и љубав према себи садрже социјални аутоматизам: милосрђе је у људима јер је добро за њих саме. Свима је важна добробит заједнице, родитеља, партнера, пријатеља, прихватање других. Људи усрећују друге људе јер и сами воле туђе задовољство. Људи су друштвена бића јер њима самима то користи. Ово се не мора прво учити, то је саставни део сваког човека. Људи су брижни, љубазни, услужни, показују се као солидарни и пожртвовани јер им то представља радост.

Али ако људе ипак треба одгајати као пуноправне људе у складу са традиционалним концептом човека, њихова љубав према себи је поремећена. А онима који не могу да воле себе такве какви јесу, биће тешко да другој особи приђу природно спонтано и да се о њој тако спонтано брину - не само површно или на начин зависан од уважавања. Они који себе заправо не воле тешко могу да се побрину за себе на одржив начин - у овом случају осмех другог, што је добро за нас. Социјална димензија човека онда вене, други му увек недостаје. Резултат је егоизам, са одговарајућим мукотрпним програмима учења. Љубав према себи, међутим, супротстављена је егоизму. Љубав према себи, према речима Шонебека, кључ је људске социјалности. Позитиван став према сопственим грешкама човеку заправо пружа више слободе и простора за њихово превладавање, као и за толерантнији став према слабостима других. 


\section{3. Васпитање и постпедагогија данас}

\section{1. Постмодерна и педагогија}

Данас није добро говорити о педагошком односу са дететом, а занемарити већ деценијама у западном свету постојећа сазнања о „крају историје“, упозорења на еколошку катастрофу, постмодернистичка искуства о обесмишљености постојања и зебњи пред неизвесношћу и тако даље. Суочавањем са крајем хуманизма, са егзистенцијалном угроженошћу човека у доба постмодерне, данас постоји дилема да ли је уопште могућа нова и другачија, искуствено, теоријски и методолошки заснована педагошка теорија љубави (и, уопште, равноправног односа између одраслог и детета). На којим је аксиолошким и епистемолошким основама могуће (у западном свету) данас заснивати односе са децом? Према Исидору Граорцу, све противречности одрастања, формирања личности детета и човека у савременом свету није могуће разумети мишљењем које не представља филозофију истог тог, савременог света (према: Живковић, 2010).

Седамдесетих година прошлог века, у радовима немачке теоретичарке Катарине Ручки (Rutschky, приредила збирку текстова: Црна педагогија) извршена је оригинална критичка реконструкција педагошке прошлости западног света. Педагошко мишљење је дезавуисано као одбрана нагонских тенденција одраслих које су изашле на видело у односима са децом. Педагогија је нека врста интелектуализације конфликтног односа према детету, написала је тада Катарина Ручки (1988). Публициста Екехард фон Браунмил је, такође, умногоме разобличио апсурдност ноторне чињенице по којој педагогија има монопол на мишљење о односу одраслих са децом. Деци нису потребни, подвлачи он, никакви педагошки захтеви да би развили осећај самосталности (према: Живковић, 2010).

У постмодерном свету нема владавине апсолутних вредности. Све је релативно, плурализам и различитости конституишу човеков свет (Шонебек, 2006: 48). Шонебекова интерпретација недирективног приступа Карла Роџерса садржи следеће елементе: а) безусловно прихватање, б) конгруентност и в) саосећање. Према Шонебеку то су основни елементи нових односа које он још назива Пријатељство са децом (Шонебек, према Граорац, 2015).

Потекао из ранијих идеја антиауторитарног васпитања и антипедагогије, покрет постпедагошког мишљења и праксе не представља само протест и негацију досадашње педагогије и васпитања, него садржи, негде више негде мање, експлицитан теоријски и методолошки програм изразито хуманистичке оријентације. Може се рећи да су постпедагошки мислиоци они који теоријски осмишљавају праксу односа са децом без васпитања, на основу теоријских сазнања, унутрашњег држања и специфичне постпедагошке етике (Живковић, 2010).

Однос педагогије и анти/постпедагогије, најбоље се можда види из разјашњења шта антипедагогија није. Тако антипедагогија не значи да више не 
треба одгајати децу - она је, у ствари, усмерена против прописане улоге у односима између васпитача и васпитаника. Антипедагогија не значи да су научна сазнања о васпитним процесима сувишна. Педагошка истраживања не смеју бити ограничена само на иманентна испитивања, него и их треба користити и усмерити и на разјашњавање скривених механизама социјализације (имплицитну педагогију). Антипедагогија није против примењивања васпитних мера, али она показује да су такве мере тек онда смислене кад се не примењују у оквиру уобичајене хијерархије, услед чега оне губе педагошко значење. Антипедагогија не значи заговарање антиауторитарног васпитања, јер она сматра да ни ово васпитање не укида саме структуре моћи. Антипедагогија не значи да унутар институција више не треба да влада никакав ред. Када критикује педагошке институције (школу, породицу...), антипедагогија није за њихово укидање, она хоће само да разјасни каквом друштвеном циљу оне служе (X. Купфер, према Граорац, 2015: 186 -187).

Педагогија данас мора преиспитати своје темеље. Микановић истиче да је за педагогију као науку нужно да се открију узроци појава антипедагошких ставова и да се прихвати оправдана критика педагошке теорије и праксе васпитања, као и да се чврсто одбаци једностраност у односу на педагогију као неопходну, значајну и интегрисану науку о васпитању. Отуда је за савремену педагошку науку прихватљива свака конструктивна критика, без обзира да ли она долази од педагога или антипедагога. Савремени педагози управо зато морају више бити рефлексивни критичари и педагошке теорије и праксе, односно педагошке науке у целини. Другим речима, и сами педагози до одређене мере треба да буду антипедагози, посебно онда када се ради о промовисању педагошких решења која немају релевенатно теоријско и емпиријско утемељење (Микановић, 2016).

Шонебек са становишта „конструктивне постмодерне“ или терапеутског односа види могућност хармонизовања и хуманизовања односа одраслог и детета (према Граорац, 2015). На децу се сада гледа другим очима. Према речима Шонебека, долазе нови људи из конструктивне постмодерне у којој се равноправност признаје као темељ свих феномена. Ако се парадигма о равноправности озбиљно узме и постави као темељ тада не постоји више разлика између формираног човека (одраслог) и још не формираног човека (детета) (Шонебек, 2006).

Равноправност као једнака вредност детета и одраслог окосница је концепција многих савремених теоретичара, те ваља поменути овде још једног, данског, код нас доста превођеног, породичног терапеута, говорника, аутора и педагога, Јеспера Јула (Jasper Juul), који је формулисао нов прилаз васпитању, односно нов систем вредности за савремене породице. Његов револуционарни приступ да су „реакције деце увек компетентне“, смислене и садржајне, и да је васпитавање у традиционалном смислу непримерено данашњим условима, представља основу система који промовише, а који се не заснива на ауторитарној примени силе „нити на тиранији демократске једнакости“, већ на једнаким вредностима и реципроцитету између деце и одраслих. Његова порука је да су деца јединствена, 
самосвесна, одговорна и да би се требало према њима односити са истим поштовањем и тактом као и према одраслима које волимо (Jul, 2017). Ову поруку налазимо и код исто тако револуционарног говорника, клиничког психолога Томаса Гордона (Thomas Gordon), иначе колеге Карла Роџерса, који је широко препознат као пионир у подучавању вештинама комуникације и метода решавања сукоба међу родитељима, наставницима, вођама, младима итд. Модел који је развио описује и у својим делима и програмима (Гордон, 2006), говорећи о вештинама активног слушања и договора без губитника и како употребити ове драгоцене вештине ради подизања самопоуздане и одговорне деце.

Традиционална педагогија, према ставовима њених савремених критичаpa, у доба постмодерне нема више своју перспективу. Како Шонебек (Šonebek, 2002) најављује: педагошко мишљење, које је израз патријархата, заједно са патријархатом припада прошлости, место му је у музеју.

\section{2. Потреба за васпитањем у постпедагошкој мисли}

Тврдња да је дете одговорно за себе од самог рођења директно се коси са педагогијом која тврди да дете још увек није одговорно биће него се оно током развоја учи одговорности, и да пуновредна личност постаје тек васпитањем (Граорац, 2007). Захтев за укидањем васпитања и образовања настао је из суочења неких људи (Маслов, Роџерс, Шонебек) са проблемом аутентичности њихових односа са децом, као мисија и позив другим људима на слично преиспитивање. Постпедагошка критика и лично искуство неких присталица ове струје обавезује нас да изнова дефинишемо васпитање.

Васпитање се разуме као намерна припрема за развијање дечјих и човекових способности. За постпедагоге је васпитање - израз технолошке рационалности која „тера“ човека да се развија, а истовремено и резултат ирационалности која произилази из принуде на такав разум (Ручки, 1988). Односно, васпитање је процес у коме деца не смеју да буду оно што осећају да јесу, уче се неаутентичности и дволичности, и, како Шонебек наглашава - у процесу васпитања лицемерје постаје природни однос (Шонебек, 2006).

Према амикативном схватању, сви су од почетка пуноправна особа, особа која носи са собом сва права и достојанство. Нико не мора да ради на себи, да се усавршава или да се образује да би постао „права“ или „боља“ особа, јер је свако у сваком тренутку свог живота пуноправна особа. Можете се променити у било ком тренутку. Људи се рађају са способношћу да буду одговорни за себе и да виде шта је најбоље за њих. Ово није систем који се мора развијати током одрастања, већ вештина која постоји од самог почетка. Самоодговорност се никада заиста не губи, шта год да се догоди у животу. Према амикативном схватању, ништа и нико не стоји изнад или испод другог: примењује се парадигма једнаке вредности свих појава. У амикативној концепцији људи тумаче свет на свој субјективни начин. Објективне истине одвојене од људи заправо не постоје. Научно знање је на крају и знање конкретних људи са њиховим субјективним погледом на свет и подложно је променама у историји. То значи да нико 
не може с правом учинити свој поглед на ствари обавезујућим за некога другог („Види то, у праву сам!“), већ свако објављује само свој, субјективни став.

У породици која подиже децу без васпитања, велики и мали људи се међусобно опходе једни са другима тако како одговара њиховим тренутним осећањима. Ако хоће да плачу, они плачу, ако хоће да се смеју, они се смеју, ако хоће да су агресивни, агресивни су. Међутим, пријатељ детета у правом смислу речи постаје тек онај ко у себи више не носи слику о човеку (детету) као бићу коме је васпитање потреба. Докле год се неко осећа одговорним за децу и њихов развој, он се још увек налази на педагошким позицијама. Тек се приступ деци без осећања одговорности за њих може назвати постпедагошким односом, или праксом. Шонебек не види да је неко од великих педагога ово остварио, ни Русо, ни Коменски, Кант, Песталоци, Фребел, Петерсен, Корчак, Нил, Френе, Макаренко, Монтесори нити било који други. У њиховим делима он не налази спремност да одустану од своје одговорности за децу, чак напротив, према речима Граорца (2007) нарочито велики педагози су више него други били пуни одговорности за децу.

\section{3. Актуелност концепције}

Постоји ли код нас спремност да се о педагогији мисли сасвим другачије у односу на концепт из педесетих година XX века? - пита се Граорац (2015). Од седамдесетих година јављају се покушаји преиспитивања полазишта, критике, али без значајнијег одјека. У доминантним токовима мисли се исто као пре неколико деценија, закључује овај педагог на скупу на коме са жалошћу износи чињеницу да је прошло више од три деценије од како објављује радове о антипедагогији и преводи Шонебекове антипедагошке текстове, а да се нико на њих није озбиљно осврнуо. Наглашавајући да су збивања у друштву и култури, у ствари, плодно тле за пропитивања, критике и постпедагошку мисао, Граорац истиче да „педагози који не виде у антипедагогији ништа плодно за педагогију не разумеју време ни стварни живот одраслих и деце данас, нити наше постсоцијалистичко друштво“ (2015: 178).

Према Живковићу (2010), најсистематичније развијен позитивни програм постпедагогије налази се у радовима Хуберта фон Шонебека (Schönebeck) и његовом удружењу Freundschaft mit Kindern, касније Amication у Минстеру у Немачкој. Шонебек и његови сарадници су у својим тренинзима самоодговорности (Selbstverantwortung Training) на одсудан начин поставили питања постмодерне етике индивидуалне одговорности у односима са децом.

Примена постпедагошке концепције је нарочито нужна данас када је свеприсутна и очигледна дисоцијација образовања и васпитања: образовање се своди на тзв. утилитарно образовање - обучавање, односно на професионалну обуку, а васпитање, у класичном смислу, бива замењено „рационализацијом разних менаџерских стратегија које доводе до профита, а не до стварања праведног и хуманог друштва““ (Цолић, 2016: 3). Нажалост, савремена образовна парадигма не подржава формирање хармоничне личности, човека који би живео у максималном сагласју са природом - космосом и својом непосредном околином, већ устројава образовање (тј. прилагођавање) човека за живот у но- 
вом техничко-кибернетичком друштву које првенствено одређују материјални, прагматички интереси. Такво образовање је у служби капитала, а за његове потребе образују се некритични, пасивни и покорни конзументи.

Неприкосновеност коју негују наставници у школама, нарочито забрањивањем дијалошког односа и размене мишљења, доводи, заправо, до занемаривања. Како Бојанин закључује, принцип „да увек треба да се зна ко је ту од кога старији и ко је дошао кога да подучава - има злу намеру“ (Бојанин, 2011: 189). Као последица се дешава и то да у каснијим разредима, када и дође до дијалошког односа, али не и одговорности за њега, дијалог постаје испразан: без поштовања саговорника, без прикладне емоционалне пратње и без труда да се аргументација заснива било на наученим знањима, било на промишљању стечене информације, било на проживљеним сопственим искуствима“" (Бојанин, 2011: 187). Уосталом, како и да дође до проживљеног искуства, када деци оно није омогућено у традиционалном васпитању и школовању у коме се дешава да ученици веома успешно заврше основне, па и средње школе, а да онда не знају куда даље. Ово говори о недостатку развијања идентитета током школовања, што је последица недостатка дијалога у настави, преоптерећености ученика градивом које све брже застарева у веку интернет технологије и доступности свих информација.

Подржавање уместо образовања сада је реалан и конструктиван постпедагошки одговор на сваки образовни концепт за мајке и очеве, наставнике и педагоге који траже излаз из свакодневне расправе о образовању. Равноправни односи успоставиће се, сматрају постпедагози, када се одрасли одрекну васпитања и неоснованог убеђења да је човек, дете - homo educandus, биће којем је васпитање потреба и где разум има водећу функцију. Постпедагози насупрот овом уверењу наглашавају зато улогу осећаја, интуиције и других мало мање поузданих, па због тога и мање познатих и изучаваних човекових моћи, као извора ништа мање вредног за схватање и доживљавање света. Постпедагози сматрају да је слободно деловање човека последица, резултат, усклађености деловања и осећаја који код детета постоји од почетка. Зато на осећајима треба радити, и на њих се ослањати, више их изражавати, односно, отворити простор за њихово појављивање (Pranjić, 2012).

Из расправа савремених постпедагога одлучно следи закључак да морамо преиспитати животну филозофију и тако темељно променити филозофију васпитања. Одрасли - службеници, родитељи, учитељи и тако даље, морају повећати своју одговорност, одговорност према себи као личности наспрам друге личности - у овом случају - детета.

Уважавајући критике постпедагогије, васпитно-образовни процес у институцијама треба динамизирати, успоставити партнерске односе између свих субјеката, све процесе у васпитању заснивати на принципима еманципације и инклузивности. Савремена педагошка пракса мора бити еманципаторска и за васпитанике и за васпитаче, она мора бити место сусрета, интеракције, комуникације, вредновања, рефлексије (Микановић, 2016). Само тако се педагошка пракса - однос одраслих и деце - може унапредити и приближити циљевима којима тежи постпедагогија, наизглед утопистичким, а заправо врло усклађеним са временом у коме живимо. 


\section{Закључна разматрања}

Намера овог рада била је да се на основу проучаване литературе изнесу опште карактеристике постпедагогије и одреди однос постпедагогије и васпитања, традиционално схваћеног. Анализа је показала да представници постпедагогије као покрета насталог крајем прошлог века и који је још увек актуелан (Ручки, Браунмил, затим Илич, Фреире, Суходолски, Нил, те Шонебек итд.) који полазе од детета, наглашавајући његову слободу, самосталност и одговорност, али и аутентичност и равноправност са одраслим, уз дубоко поштовање, прихватање и емпатију, сматрају да деци нису потребни никакви педагошки захтеви да би развили осећај самосталности. Према постпедагозима, педагошко мишљење, које је израз патријархата, заједно са патријархатом припада прошлости. Постмодерна је време у коме нема места за (традиционално схваћену) педагогију, ово је време „после педагогије“. Постпедагошко мишљење подразумева радикалан раскид са педагогијом. Равноправни односи успоставиће се, сматрају постпедагози, тек када се одрасли одрекну васпитања и неоснованог убеђења да је човек, дете - homo educandus, биће којем је васпитање потреба и где разум има водећу функцију.

Педагогија није случајно критикована од стране постпедагога. У историји развоја педагошких схватања, може се наћи много значајних педагошких мислилаца, па и читавих периода, где јеваспитање схватано као извесни дрил, строга дисциплина, повиновање и томе слично. Зато не чуди што су баш у Немачкој, где се још увек осећа строга хербартовска педагогија, иступили Браунмил, Ручки, Шонебек и остали анти/ постпедагози, критикујући такву - хербартовску педагогију. Иста је била донешена и у наше просторе и уклопљена у патријархат који је дуго био изразито присутан у односима одраслих и деце, и који је вероватно имао заштитну функцију у одређеним историјским временима, док се данас показује као врло штетан за развој детета. Такву, репресивну, педагогију ваља критиковати. С друге стране, постпедагогија је отворила простора пемисивном васпитању. Истраживања у свету показују да и пермисивно васпитање оставља последице по развој детета и да, захваљујући пермисивном васпитању, данас у свету постоје читаве генерације депресивних, нарцисоидних и анксиозних адолесцената. Зато у том вагању педагогија треба да поступи обазриво и да и ове, постмодерне, прогресивне ставове сагледа кроз културолошку перспективу нашег народа и прихвати са извесном резервом, дозирано и усклађено са осталим односима који владају у друштву. Како да направи баланс између васпитања и, постпедагошки схваћеног, не-васпитања, свакако остаје на педагогији да узме на себе обавезу да изнова данас дефинише „васпитање“.

Данас би се за језгро васпитања могла узети интеракција васпитача и детета, где је, притом, од великог значаја у ствари освешћивање тих односа. Постпедагошко схватање односа према детету није пука могућност о којој се случајно говори: оно је обележје времена у којем живимо и у којем ће наша деца тек живети. Савремено друштво утемељено на плуралистичким оријентацијама, позива одрасле да преиспитују вредности које у њиховим односима са децом имплицитно провејавају, те да и њима (односима), као и осталим подручјима живота, пруже алтернативу. 


\section{Литература}

Бојанин, С. (2011). Тајна школе. Београд: Одбор за верску наставу Архиепископије београдско-карловачке.

Гордон, Т. (2006). Умеће родитељства - како подизати одговорну деиу. Београд: Креативни центар.

Граорац, И. (2007). Поглед иза кулиса: Амикација (постпедагогија) и Марија Монтесори. Педагошка стварност, 53(3-4): 354-360.

Граорац, И. (2015). Педагогија и антипедагогија. У: (ур. Ж. Миленовић и С. Башчаревић) Зборник радова са научног скупа: Настава и наука у времену и простору (стр. 177-204). Лепосавић: Учитељски факултет у Призрену.

Gojkov, G. (2006). Didaktika i postmoderna. Vršac: Viša škola za obrazovanje vaspitača.

Guljons, H. (2002). Postmoderna i nauka o vaspitanju. Pedagogija - časopis Saveza pedagoških društava Jugoslavije, 50(3): 17-32.

Живковић, И. (2010). Педагошка љубав према детету и постпедагошка љубав према себи. Љубав и образовање: књига резимеа са међународног скупа одржаног у Новом Саду 4. јуна 2010. (стр. 9-10). Нови Сад: Висока школа струковних студија за образовање васпитача.

Jul, J. (2017). Vaše kompetentno dete. Beograd: Laguna.

Jul, J. (2018). Život u porodici. Beograd: Laguna.

Kehily, M. J. (Ed.). (2009). An introduction to childhood studies. New York: Open University Press.

Key, E. (2000). Stoleće deteta. Zagreb: Educa.

Kraljačić, D. (2016). Postmodernizam i moderni film sa posebnim osvrtom na period od 1970. godine do danas (Neobjavljena doktorska disertacija). Beograd: Univerzitet umetnosti u Beogradu, Fakultet dramskih umetnosti pozorišta, filma, radija i televizije.

Maras, N., Topolovčan, T. i Matijević, M. (2018). Konstruktivistička didaktika i neurodidaktika u diskursu reformne pedagogije - Teorijska polazišta, dileme i komparacija. Nova prisutnost, 16(3): 561-577.

Микановић, М. (2016). Антипедагогија и развој педагогије у будућности. Норма, XXI(2): 335-346.

Milutinović, J. (2011). Alternative u teoriji i praksi savremenog obrazovanja: put ka kvalitetnom obrazovanju. Novi Sad: Savez pedagoških društava Vojvodine; Vršac: Visoka škola strukovnih studija za obrazovanje vaspitača „Mihailo Palov”.

Минић, В. (2013). Педагошке идеје Марије Монтесори и њихова примена у пракси. Наше стварање. Зборник радова са Осмог симпозијума са међународним учешћем „, Васпитач у 21. веку“. Алексинац: Висока школа за васпитаче, 145 - 156.

Михајловић, Т. (2013). Научна схватања Елене Кеј и наших педагога о позицији дјетета у васпитном процесу. Педагошка стварност, 59(4): 693-707.

Педагошки лексикон (1996). Београд: Завод за уџбенике и наставна средства.

Петровић, J. (2015). Интелектуално и емоционално васпитање у реформној педагогији са почетка 20. века - актуелност изворних схватања (Необјављена док- 
торска дисертација). Нови Сад: Филозофски факултет.

Potkonjak, N. (2003). XX vek - ni vek deteta ni vek pedagogije: ima nade ... XXI vek. Novi Sad: Savez pedagoških društava Vojvodine; Banja Luka: Pedagoško društvo Republike Srpske.

Pranjić, M. (2012). Antipedagogija i suvremeni koncepti odgoja. Pedagogijska istraživanja, 9(1-2): 9-24.

Rodžers, K. (1985). Kako postati ličnost. Beograd: Nolit.

Ручки, К. (1988). Увод у црну педагогију. Идеје, (1).

Schoenebeck, H. Amication. Преузето 26.9.2020. са сајта: https://www.amication.de/

Цолић, М. (2016). Програмско-продукционо моделовање образовног програма ТВ Београд у периоду од 1964. до 1980. године, као парадигма друштвено оправдане и медијски успешне едукаиије (Необјављена докторска дисертација). Факултет драмских уметности Универзитета уметности у Београду.

Шонебек, Х. (2006). Комуникација са децом у доба постмодерне. У: Развијање комуникационих компетенција (стр. 48-58). Јагодина: Факултет педагошких наука Универзитета у Крагујевцу.

Šonebek, H. V. (2002). Antipedagogija - šta je to? Pedagogija-časopis Saveza pedagoških društava Jugoslavije, 50(3): 99-104.

\title{
POSTPEDAGOGY: CONCEPT DEVELOPMENT AND MOST SIGNIFICANT SETTINGS
}

\author{
Jelena Petrović, Marija Đorđević \\ University of Niš, Faculty of Philosophy, Department of Pedagogy
}

\begin{abstract}
The intention of this paper was to perform a theoretical analysis of the concept of postpedagogy, theoretical and practical understandings of the representatives of postpedagogy, with an emphasis on the relationship between adults and children. Also, in the analysis, we tried to determine the post-pedagogical attitude towards the traditional understanding of the term "education", as well as to touch on the relevance of this concept. Freedom and responsibility of the child, respect for the child and his subject position, but also self-love and authenticity - are the key goals and basis of the post-pedagogical conception. Post-pedagogical thinking implies a radical break with traditional pedagogy. According to postpedagogues, equal relations will be established only when adults renounce education and the belief that man, a child - homo educandus, is a being who needs education and where reason has a leading function. The postpedagogical understanding of the attitude towards the child is not a mere possibility that is accidentally talked about: it is a feature of the time in which we live and in which our children will still live. Postpedagogues call on modern society to reconsider its pedagogical values on which the relationship between adults and children is based.
\end{abstract}

Key words: amication, antipedagogy; education; relationship between adults and children; postmodern; postpedagogy.

\section{Citiranje članka:}

Petrović, J. i Đorđević, M. (2020). Postpedagogija: razvoj koncepta i najznačajnije postavke. Godišnjak za pedagogiju, 5(2), 35-49. 